\title{
The Impact of CRM on Innovation Capabilities: A Study on Industries of Pakistan
}

\author{
Farhan Ahmed $^{1 *}$, Danish Ahmed Siddiqui ${ }^{2}$ \\ ${ }^{1}$ Research Scholar, Karachi University Business School, University of Karachi, PAKISTAN \\ ${ }^{2}$ Associate Professor, Karachi University Business School, University of Karachi, PAKISTAN \\ E-mail for correspondence: farri.ahmed92@gmail.com
}

\begin{abstract}
The purpose of this research is to determine the impact of CRM on innovative capabilities where the comparative study has been conducted between the services and manufacturing industries in Pakistan. For this purpose, the factors affecting CRM include information sharing, customer involvement, longterm partnership, joint problem solving, and technology based CRM while for measuring the innovative capabilities, product innovation, process innovation, and service innovation has been used. The data collected from 60 employees working in different service and manufacturing firms in Karachi. The results show that there is a significant impact on customer involvement, joint problem solving and technology based CRM on innovation capabilities of firms. It is suggested to refrain from customer involvement because it is observed that involving the customers negatively influences the innovation capabilities of manufacturing industry and thus, it has been recommended for companies to abstain from drawing in customers. The research also suggests adding supplier integration to form more effective innovations programs.
\end{abstract}

Keywords: Customer Relationship Management (CRM), Innovation Capabilities, Service Industries, Manufacturing Industries, Information Sharing, Joint Problem Solving, Long term Partnership, Customer Involvement

\section{INTRODUCTION}

In the age of globalization and highly competitive market, the industries are facing lots of challenges to qualify the customer requirement and get their esteemed satisfaction. Catering to these challenges and get long term competitive advantages, manufacturing industries and service industries both are looking to improve their supply chain capabilities and enhance their innovation capabilities. Moreover, organizations are advised to become more innovative and flexible to respond to the customer demand for present in the market as firms cannot stay alive without regulating to an external environment and forming new ideas and commercializing them. (Shane \& Ulrich, 2004) Highlights the vital concern for the manufacturing firm, which is an effective use of innovation capabilities to control the unpredictable demand for the competitive market. Innovation is the only solution to curb problems and complexities for unpredictable demand.

Lin et al. (2010) proposes the there are five dimensions of Customer Relationship Management (CRM) i.e. (information sharing, customer involvement, technology- based CRM, long-term partnership and joint problemsolving) and five phases of innovation capability (product, process, service innovation, and marketing) which associated with each other and by using regression analysis they found that the firm could able to increase innovation capabilities by employing CRM.

This study is substantial for all the organizations either it is small or big. CRM is a strategic decision in which organizations involve their customer to participate in the improvement in product utilization. There are many types of research on the impact of CRM on Innovations have been conducted since last 30 years, but this topic never conducted on Pakistan, moreover, by comparing two industries, we further analyzed their implications of CRM on manufacturing and services in Pakistan.

We have selected Pakistan because it is one of the growing economies of Asia and still at its initial stage for the adoption of CRM. Previously, there was a trend of Pakistan's industries to produce in mass production; they produce the same product with the same features in bulk quantity. But now, tendencies are changing customer have 
become more demandable as ever before, and also markets become more competitive. Furthermore, china's products are also becoming a threat for Pakistan product. So for the survival, industries of Pakistan are adopting CRM and many others techniques to compete in this market. Hence this study uncovers whether the effect of CRM on innovation still holds when CRM is at its initial stage.

CRM is a broad study which impacts on Customer satisfaction, customer loyalty, market shares, market development, etc. However, their effects on Innovation capabilities is still less studied, as CRM helps in launching of new product or moving into new territory, it will beneficial in targeting new prospects and manage communication. The CRM will also enable the company to know why business is won or lost.

Moreover, to make this study more useful, we segregated organizations between service and manufacturing, so the objective became, to find the effectiveness of CRM on innovation capabilities in different industries. This study may give you an idea about which industry is more towards customer orientation and which CRM indicator is more significant for their innovations. Moreover, by comparing two industries, we further analyzed their implications of CRM on manufacturing and services in Pakistan.

Following are the objectives of the study:

- To find which industry (Manufacturing or service) are using CRM more efficiently in Pakistan.

- To find out and investigate how CRM implementation can affect Innovation capabilities (product, process, and service innovation) in Pakistan's organizations.

- To find out how customers give their contribution towards innovation or enhancement of the product.

The research is based on Pakistan manufacturing and service industries more specifically Karachi, which is the financial hub of Pakistan. The population of this research is the manufacturing and service industries employees, who engage with their customer and also keep vigilant eyes on marketing trends, changes, and opportunities. Questionnaire has been developed to gather valuable statistics and data for further necessary actions.

\section{LITERATURE REVIEW}

\section{Customer Relationship Management (CRM)}

Customer Relationship Management is a tool for improving business relationship by analyzing customer interaction throughout the customer relationship lifecycle. CRM is a technological application which combines front office function, i.e., Sales, Marketing and customer and back office function i.e. Administration, Logistics, Human resources, and Operations, with an organization's customer TouchPoint (Fickel, 1999). (Ramani \& Kumar, 2008) Indicates that good customer relationship management between manufacturing and its customer enables customer retention and also persuade them to give critical feedback about product and services. CRM is a tool to which firms use to improve customer tastes and preferences, which enable firms to design their product and services according to the customer (Ramani \& Kumar, 2008). The Profitable relationship is considered the right relationship, which chooses not built (Verhoef and Donkers, 2001). Other think CRM is only a tool for one to one customer communication for sales or services (Pepper \& Roger, 1999).

A CRM system will help companies to keep track of service issues, warranty, and maintenance. A CRM system manages the day to day queries, service calls, suggestions and feedback of the customer and ensures that nothing gets overlooked. CRM gathers customer's information at one place so that everyone can see the customer requirements and difficulties attach to it. By this, organization enables to craft the perfect solution to the customer. Furthermore, it allows the manufacturer and service providers to assess the entire customer base through their previous histories of requirements.

CRM helps in launching of a new product or moving into new territory; it will beneficial in targeting new prospects and manage communication. CRM is the technique, which is implemented in the organization to cut down the cost and increase profitability by strengthening customer loyalty.

\section{Factors Affecting CRM}

In this study we focus on five indicators of Customer Relationship Management, that is; Information Sharing, Long Term Partnership, Customer Involvement, Joint Problem Solving, and Technology.

Information Sharing: As discussed above, CRM main focus is the only customer. So, to retain the customer and build a customer relationship, the organization needs to know what customer demand, which can be possible through exchanging of information and coordination of events. Information sharing is referred to a bilateral approach, in which customer and company both exchange market information, new trends, etc. (Heide and John 1992).

To collect customer information organizations needs to know customer's core business, customer's import and export, customer's market, customer's organization hierarchy, and more importantly customer's customer and supplier. Information sharing referred to the effective sharing of confidential and classified information among channel partners has been regarded as trust and mutual benefits between the parties (Doney and Cannon 1997).

Customer Involvement: Customer involvement is referred to the participation of customer to design new product or services. It includes customer feedback, customer complaints, warranty claims, etc. It is crucial in CRM in a way that, it provides customer insides demand and customer interest to do business with an organization. Sin 2005, highlights customer involvement activities that are technical meeting, 
market evaluation conference, and supply chain annual conference. When the company shares you with their future needs, it means they are looking forward to collaborating on the product sales.

Long-term Partnership: Trust and commitments are the vital factor of the two businesses to build Long Term Partnership. The companies, who have to achieve similar goals and similar interest, are pursued to create a partnership on a long-term basis (Mohr and Spekman, 1994). The study of (Handfield and Bechtel, 2002) explains that Long-term partnership requires mutual understanding and fair high level of commitment to share in resources effectively to gain mutual benefits. Moreover, rooted in mutual trust and mutual understanding, organizations can uphold close partnerships with the customers, identify customer demands, and thus offer an acceptable pricing scheme, retailing and marketing strategies and promotion activities (Lin and Germain, 2004).

Joint Problem Solving (JPS): Joint Problem solving is a mutual and cooperative approach, in which both parties (Company and customer) interact and find out a solution which causes mutual befits for both the parties. Kepner and Tregoe (1965) defined that JPS is a scientific approach, which starts from problem definition moved to a comparison of non-problem situation, and problem situation then analyze the causes and finally form a master plan.

JPS exerts a positive impact on the success of product, services and market enlargement. Ritter and Walter (2003) said that it would be an easy way for manufacturers and service providers to develop product quality and scientific process.

Technology-based CRM: Technology-based CRM includes computer and digital technologies to assist various CRM processes and actively offer enhanced technology support to customers, together with data mining, data storage, web portals and CRM software (Sin et al., 2005).

Muhmin, 2012 writes that CRM technology and its use play a vital role in emerging market by using variables of CRM awareness, CRM Technology use, CRM technology adoption and duration of using CRM technology found that CRM technology is far useful for large-scale organizations, which have a large scale of the customer base. He also constructed that adoption of technology increase employee productivity and customer satisfaction. Technology intensifies the intelligence capabilities of CRM greatly. Accurate customer information and data is essential for CRM performance.

\section{Innovation Capabilities}

An idea or practice which is new to an individual or something which had never tasted or used by any businesses is an Innovations (Fruhling and Siau 2007). Innovation refers to the development of new technologies, policies, products, processes or services which is advanced for an organization (Chang \& Lee 2008). An ability of a firm to transform information and knowledge to a new creation or development is known as innovation capabilities.

According to Schumpeter, an innovation means "new combinations" to produce something by utilizing the capability of materials and work force. This new combination can be; to produce new thing with the same technology or process, or to produce the same thing with new technology or processes. He also elaborated the word "new combination" is that a product which had never consumed a technology which had never experienced before and a market which never targeted previously.

Product Innovation: Product Innovation is an introduction and development of a new product into the market or modification of existing products concerning its features, specifications, functions, and quality (Liao 2007). For product innovation, an organization needs to use new knowledge, data or technologies or a mixture of these with the existing knowledge and automaton.

Process Innovation: Process innovation is accomplishing and implementing a delivery method or use an improved production method that must be in the shape of fundamental changes in approach, technology, equipment or software. Process innovation is an adoption of new elements that may include material, software, technology, and information flow to the organization's production process (Damanpour, 1996). Process innovation can be useful for both employees and customer at the same time. It may provide ease to employees and also improve quality at the same time. So it can be said that innovation in the process may increase service level, reduce human tasks and improved product quality.

Service Innovation: Service Innovation is a manufacturers' engagement in different innovation activities to improve customer satisfaction, including, warranty policy, after-sale services, order placement systems, and maintenance routines, (Gopalakrishnan and Damanpour, 1997). Service innovation is referred to change the methods and ways to serve the customer and generate greater values and benefits to the customer as well as the organization.

\section{Conceptual Framework}

\begin{tabular}{|l|}
\hline Information Sharing \\
\hline Customer Involvement \\
\hline Long term Partnership \\
\hline Joint Problem Solving \\
\hline Technology based CRM \\
\hline
\end{tabular}$\Rightarrow$\begin{tabular}{|l|}
\hline Product Innovation \\
\hline Process Innovation \\
\hline Service Innovation \\
\hline
\end{tabular}

\section{Hypothesis}

$\mathrm{H}_{1}$ : Information Sharing is more significant for innovation in the manufacturing industry than service Industry. 
$\mathrm{H}_{2}$ : Joint Problem solving is more significant for innovation in the manufacturing industry than service Industry.

$\mathrm{H}_{3}$ : Customer involvement is more significant for innovation in the manufacturing industry than service Industry.

$\mathrm{H}_{4}$ : Technology-based CRM is more significant for innovation in the manufacturing industry than service Industry.

$\mathrm{H}_{5}$ : Long-Term Partnership is more significant for innovation in the manufacturing industry than service Industry

\section{Research Methodology}

The conduction of this study, the researcher, has opted to use survey questionnaire based on close-ended questions and measured on a five-point Likert scale to collect data numeric coded form from respondents.

For testing the impact of CRM on innovation capabilities, the techniques utilized in this research include reliability analysis, correlation analysis, and regression analysis. We used SPSS software for our analysis

Since this study is related to the service and manufacturing industry of Pakistan, however the research sample for this study is the firms operating in the manufacturing and service sector of Karachi. Specifically, the employees working in the firms above are the part of the sample for this study. Since the number of employees working in firms is extensive, therefore, the sample size selected for this study due to limited time is 60 respondents. This study has chosen the convenience sampling technique to select the participants from whom data is to collect.

\section{FINDINGS AND ANALYSIS}

The following study was carried out with the help of primary data collected from the employees working in the manufacturing and service industries of Pakistan. The sample size $(\mathrm{N})$ was 60 , and all questions were successfully answered. The researcher had used reliability, correlation, T-test and regression tests to present the results. We used SPSS to obtain tests results.

\section{Reliability Test}

Reliability and validity are crucial in research methodology, to assess the accuracy of the research instrument used such as survey questionnaire. In the light of the study conducted by Creswell (2017), it determines that reliability is defined as the consistency of the research instrument where similar results are obtained when tested more than once.

\begin{tabular}{|c|c|c|c|}
\hline \multicolumn{4}{|c|}{ Case Processing Summary } \\
\hline & & $\mathrm{N}$ & $\%$ \\
\hline \multirow[t]{3}{*}{ Cases } & Valid & 60 & 100.0 \\
\hline & Excluded ${ }^{3}$ & 0 & .0 \\
\hline & Total & 60 & 100.0 \\
\hline
\end{tabular}

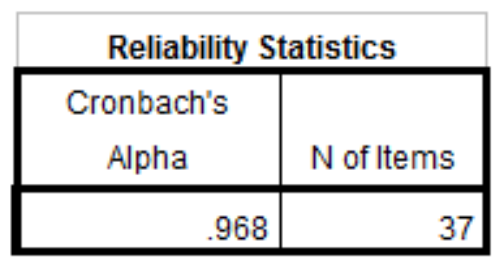

The figures above show the results of reliability tests with 60 respondents. The first table shows that SPSS has successfully accepted the data of 60 respondents and will provide reliable results whereas the second figure shows the percentage of Cronbach's Alpha that is, 0.968 or $96.8 \%$. Cronbach's Alpha shows the internal consistency of the items in the research instrument. With 37 questions in the survey questionnaire, the Cronbach's Alpha is $96.8 \%$ which indicates that all the items in the questionnaire are closely related with each other or there is high-level of internal consistency.

\section{Demographic Profile}

Following are the results obtained for five demographic questions asked from the employees through the survey questionnaire:

\begin{tabular}{|c|c|c|c|c|c|}
\hline \multicolumn{6}{|c|}{ Industry } \\
\hline & & Frequency & Percent & Valid Percent & \begin{tabular}{|c} 
Cumulative \\
Percent
\end{tabular} \\
\hline \multirow[t]{3}{*}{ Valid } & Manufacturing & 38 & 63.3 & 63.3 & 63.3 \\
\hline & Service & 22 & 36.7 & 36.7 & 100.0 \\
\hline & Total & 60 & 100.0 & 100.0 & \\
\hline
\end{tabular}

Industry background of 60 respondents; 38 work in manufacturing industry whereas only 22 work in the service industry. The results show that $63.3 \%$ of employees work in manufacturing industry.

\begin{tabular}{|l|c|c|c|c|c|}
\hline \multicolumn{5}{|c|}{ Firm Size } \\
\hline \multirow{2}{*}{} & Frequency & Percent & Valid Percent & $\begin{array}{c}\text { Cumulative } \\
\text { Percent }\end{array}$ \\
\hline \multirow{2}{*}{ Valid } & Small Size firm & 20 & 33.3 & 33.3 & 33.3 \\
\cline { 2 - 6 } & Medium size firm & 28 & 46.7 & 46.7 & 80.0 \\
\cline { 2 - 6 } 2.00 & 12 & 20.0 & 20.0 & 100.0 \\
\hline \multicolumn{2}{|l|}{ Total } & 60 & 100.0 & 100.0 & \\
\hline
\end{tabular}

The second question asked from the respondents was about the size of their firm. Out of 60 employees, 20 had small firm size, 28 had a medium size of the firm and only 12 had large size of firm. Results indicate that most of the employees work in medium size of firms followed by small and large size.

\begin{tabular}{|c|c|c|c|c|c|}
\hline \multicolumn{6}{|c|}{ Software/System Implemented } \\
\hline & & Frequency & Percent & Valid Percent & $\begin{array}{l}\text { Cumulative } \\
\text { Percent }\end{array}$ \\
\hline \multirow[t]{4}{*}{ Valid } & Orcale & 14 & 23.3 & 23.3 & 23.3 \\
\hline & ERP & 34 & 56.7 & 56.7 & 80.0 \\
\hline & Other & 12 & 20.0 & 20.0 & 100.0 \\
\hline & Total & 60 & 100.0 & 100.0 & \\
\hline
\end{tabular}


Out of 60, 14 employees answered oracle, 34 answered ERP system whereas only 12 answered as "other." Results indicate that ERP is a more common software system that is implemented in several organisations.

\begin{tabular}{|c|c|c|c|c|c|}
\hline \multicolumn{6}{|c|}{ Duration of Software/System Implemented } \\
\hline & & Frequency & Percent & Valid Percent & $\begin{array}{l}\text { Cumulative } \\
\text { Percent }\end{array}$ \\
\hline \multirow[t]{5}{*}{ Valid } & Less than 1 year & 4 & 6.7 & 6.7 & 6.7 \\
\hline & 2 to 3 years & 16 & 26.7 & 26.7 & 33.3 \\
\hline & 3 to 5 years & 27 & 45.0 & 45.0 & 78.3 \\
\hline & More than 5 years & 13 & 21.7 & 21.7 & 100.0 \\
\hline & Total & 60 & 100.0 & 100.0 & \\
\hline
\end{tabular}

Out of 60 respondents, four responded that it took less than a year, 16 replied that it took 2 to 3 years, 27 answered that it took 3 to 5 years and finally, 13 answered that it took more than five years. The answer to this question entirely depends on the type of software implemented in a large, medium or small sized firm.

\begin{tabular}{|c|c|c|c|c|c|}
\hline \multicolumn{6}{|c|}{ Designation } \\
\hline & & Frequency & Percent & Valid Percent & $\begin{array}{c}\text { Cumulative } \\
\text { Percent }\end{array}$ \\
\hline \multirow[t]{5}{*}{ Valid } & Executive & 8 & 13.3 & 13.3 & 13.3 \\
\hline & Manager & 26 & 43.3 & 43.3 & 56.7 \\
\hline & Vice President & 18 & 30.0 & 30.0 & 86.7 \\
\hline & Director & 8 & 13.3 & 13.3 & 100.0 \\
\hline & Total & 60 & 100.0 & 100.0 & \\
\hline
\end{tabular}

The last demographic question asked from the respondents was related to their designation in organization they are working. Out of 60 respondents, eight worked as executives, 26 were managers, 18 were vice presidents, and eight were directors.

\section{Correlation Analysis}

\begin{tabular}{|c|c|c|c|c|}
\hline \multicolumn{5}{|c|}{ Correlations } \\
\hline & & $\begin{array}{c}\text { Lont_Term_Part } \\
\text { nership }\end{array}$ & $\begin{array}{c}\text { Information_Sh } \\
\text { aring }\end{array}$ & $\begin{array}{c}\text { Customer_Invol } \\
\text { vement }\end{array}$ \\
\hline \multirow{3}{*}{$\begin{array}{l}\text { Lont_Term } \\
\text { Partnership }\end{array}$} & Pearson Correlation & 1 & $.881^{-}$ & $.763^{-}$ \\
\hline & Sig. (2-tailed) & & .000 & .000 \\
\hline & $\mathrm{N}$ & 60 & 60 & 60 \\
\hline \multirow{3}{*}{$\begin{array}{l}\text { Information } \\
\text { Sharing }\end{array}$} & Pearson Correlation & $.881^{-}$ & 1 & $.812^{-}$ \\
\hline & Sig. (2-tailed) & .000 & & .000 \\
\hline & $\mathrm{N}$ & 60 & 60 & 60 \\
\hline \multirow{3}{*}{$\begin{array}{l}\text { Customer } \\
\text { Involvement }\end{array}$} & Pearson Correlation & $.763^{-}$ & $.812^{-}$ & 1 \\
\hline & Sig. (2-tailed) & .000 & .000 & \\
\hline & $\mathrm{N}$ & 60 & 60 & 60 \\
\hline \multirow{3}{*}{$\begin{array}{l}\text { Joint_Problem } \\
\text { Solving }\end{array}$} & Pearson Correlation & $.454^{-}$ & $.493^{-}$ & $.445^{\circ}$ \\
\hline & Sig. (2-tailed) & .000 & .000 & .000 \\
\hline & $\mathrm{N}$ & 60 & 60 & 60 \\
\hline \multirow{3}{*}{$\begin{array}{l}\text { Technology } \\
\text { Based_CRM }\end{array}$} & Pearson Correlation & $.848^{-}$ & $.990^{-}$ & $.831^{-}$ \\
\hline & Sig. (2-tailed) & .000 & .000 & .000 \\
\hline & $\mathrm{N}$ & 60 & 60 & 60 \\
\hline \multirow{3}{*}{$\begin{array}{l}\text { Innovation } \\
\text { Capabilities }\end{array}$} & Pearson Correlation & $.741^{-}$ & $.861^{-}$ & $.618^{-}$ \\
\hline & Sig. (2-tailed) & .000 & .000 & .000 \\
\hline & $\mathrm{N}$ & 60 & 60 & 60 \\
\hline
\end{tabular}

Correlation analysis describes as the statistical method used to find the association between two variables. It shows whether there is a significant association between independent and dependent variables.

\begin{tabular}{|c|c|c|c|c|}
\hline \multicolumn{5}{|c|}{ Correlations } \\
\hline & & $\begin{array}{c}\text { Joint_Problem_ } \\
\text { Solving }\end{array}$ & $\begin{array}{c}\text { Technology_Bas } \\
\text { ed_CRM }\end{array}$ & $\begin{array}{c}\text { Innovation_Capa } \\
\text { bilities }\end{array}$ \\
\hline \multirow{3}{*}{$\begin{array}{l}\text { Lont_Term } \\
\text { Partnership }\end{array}$} & Pearson Correlation & $.454^{-}$ & $.848^{-}$ & $.741^{-}$ \\
\hline & Sig. (2-tailed) & .000 & .000 & .000 \\
\hline & $\mathrm{N}$ & 60 & 60 & 60 \\
\hline \multirow{3}{*}{$\begin{array}{l}\text { Information } \\
\text { Sharing }\end{array}$} & Pearson Correlation & $.493^{-}$ & $.990^{-}$ & $.861^{-}$ \\
\hline & Sig. (2-tailed) & .000 & .000 & .000 \\
\hline & $\mathrm{N}$ & 60 & 60 & 60 \\
\hline \multirow{3}{*}{$\begin{array}{l}\text { Customer } \\
\text { !nvolvement }\end{array}$} & Pearson Correlation & $.445^{\circ}$ & $.831^{-}$ & $.618^{-}$ \\
\hline & Sig. (2-tailed) & .000 & .000 & .000 \\
\hline & $\mathrm{N}$ & 60 & 60 & 60 \\
\hline \multirow{3}{*}{$\begin{array}{l}\text { Joint_Problem } \\
\text { Solving }\end{array}$} & Pearson Correlation & 1 & $.513^{-}$ & $.572^{-}$ \\
\hline & Sig. (2-tailed) & & .000 & .000 \\
\hline & $\mathrm{N}$ & 60 & 60 & 60 \\
\hline \multirow{3}{*}{$\begin{array}{l}\text { Technology } \\
\text { Based_CRM }\end{array}$} & Pearson Correlation & $.513^{-}$ & 1 & $.871^{-}$ \\
\hline & Sig. (2-tailed) & .000 & & .000 \\
\hline & $\mathrm{N}$ & 60 & 60 & 60 \\
\hline \multirow{3}{*}{$\begin{array}{l}\text { Innovation } \\
\text { Capabilities }\end{array}$} & Pearson Correlation & $.572^{-}$ & $.871^{-}$ & 1 \\
\hline & Sig. (2-tailed) & .000 & .000 & \\
\hline & $\mathrm{N}$ & 60 & 60 & 60 \\
\hline
\end{tabular}

The dependent variable in this study was innovation capabilities whereas independent variables were longterm partnership, information sharing, customer involvement, joint problem solving and technology-based CRM. The table above shows the results of the correlation. The essential values that are used for interpretation of results are Pearson correlation and significance value.

The correlation between long-term partnership and innovation capabilities is $74.1 \%$, and significance value is 0.000 . It indicates that significant association exists between long-term partnership and innovation capabilities.

The correlation between information sharing and innovation capabilities is $86.1 \%$, and significance value is 0.000 . It indicates that significant association and correlation exists between information sharing and innovation capabilities.

The correlation between customer involvement and innovation capabilities is $61.8 \%$, and significance value is 0.000 . It indicates that significant association exists between customer involvement and innovation capabilities.

The correlation between joint problem solving and innovation capabilities is $57.2 \%$, and significance value is 0.000 . It indicates that significant correlation exists between joint problem solving and innovation capabilities.

The correlation between technology-based CRM and innovation capabilities is $87.1 \%$, and significance value is 0.000 . It indicates that significant association and correlation exists between technology based CRM and innovation capabilities.

Overall, results of correlation analysis indicate that all independent variables have significant association and correlation with innovation capabilities. The results 
validate the study conducted by Smith and Chang (2010) which highlights that CRM is a customer-centric system which encourages innovation through different demand dimensions of customers.

\section{Regression Analysis}

Regression analysis is the statistical method used for determining the relationship between dependent and independent variables. Most of the statistically based studies use regression analysis to validate their studies for finding a relationship between variables is significant or not-

\begin{tabular}{|l|c|c|c|c|}
\hline \multicolumn{5}{|c|}{ Model Summary } \\
\hline Model & $R$ & $R$ Square & $\begin{array}{c}\text { Adjusted R } \\
\text { Square }\end{array}$ & $\begin{array}{c}\text { Std. Error of the } \\
\text { Estimate }\end{array}$ \\
\hline 1 & $.906^{\mathrm{a}}$ & .821 & .804 & .22535 \\
\hline
\end{tabular}

The first table of regression analysis is the model summary. The model summary shows R-value, R-square and adjusted R-square. The R-value shows the correlation value that is $90.6 \%$ whereas $R$-square shows that $82.1 \%$ of the variation in innovation capabilities can be explained with other independent variables such as long-term partnership, information sharing, customer involvement, joint problem solving and technology-based CRM. The model summary also indicates that a higher value of $R$ and $\mathrm{R}$-square shows a stronger degree of correlation between the dependent and independent variables.

\begin{tabular}{|c|c|c|c|c|c|c|}
\hline \multicolumn{7}{|c|}{ ANOVA $^{a}$} \\
\hline \multicolumn{2}{|c|}{ Model } & Sum of Squares & df & Mean Square & $\mathrm{F}$ & Sig. \\
\hline \multirow[t]{3}{*}{1} & Regression & 12.540 & 5 & 2.508 & 49.387 & $.000^{\circ}$ \\
\hline & Residual & 2.742 & 54 & .051 & & \\
\hline & Total & 15.282 & 59 & & & \\
\hline
\end{tabular}

With the help of the table of ANOVA, the dependent variable can be assessed which is innovation capabilities in this case. The two values used for analysis from the above table are F-statistics and significance value. The significance value shown in the above table is 0.000 which is less than 0.05 hence, indicating heathy and significant relationship. On the other hand, f-statistics value shows variance in the dependent variable. Moreover, it is also used for the purpose of finding whether the null hypothesis designed in the earlier section was accepted or rejected.

\begin{tabular}{|c|c|c|c|c|c|c|}
\hline \multicolumn{7}{|c|}{ Coefficients $^{\mathrm{a}}$} \\
\hline \multirow{2}{*}{\multicolumn{2}{|c|}{ Model }} & \multicolumn{2}{|c|}{$\begin{array}{l}\text { Unstandardized } \\
\text { Coefficients }\end{array}$} & \multirow{2}{*}{\begin{tabular}{|c|}
$\begin{array}{c}\text { Standardized } \\
\text { Coefficients }\end{array}$ \\
Beta \\
\end{tabular}} & \multirow[t]{2}{*}{$t$} & \multirow[t]{2}{*}{ Sig. } \\
\hline & & $B$ & Std. Error & & & \\
\hline \multirow[t]{6}{*}{1} & (Constant) & 1.107 & .087 & & 12.788 & .000 \\
\hline & Lont_Term_Partnership & .092 & .092 & 138 & 1.001 & .321 \\
\hline & Information_Sharing & -.197 & .254 & -.391 & -.775 & .442 \\
\hline & Customer_Involvement & -.256 & .073 & -.388 & -3.518 & .001 \\
\hline & Joint_Problem_Solving & .070 & .028 & 169 & 2.479 & .016 \\
\hline & Technology_Based_CRM & .726 & .254 & 1.376 & 2.860 & .006 \\
\hline
\end{tabular}

The last table of regression analysis is the table of coefficients. It provides information about how innovation capabilities are influenced or affected by CRM in manufacturing and service industries of Pakistan. From the table above, the sig-values are taken under consideration to find a relationship. It is evident that out of 5 independent variables, customer involvement, joint problem solving, and technology-based CRM has significant relationship with innovation capabilities as all sig-values of these three variables are less than 0.05 .

\section{T-Test}

From the independent sample t-test, the mean comparison for service and manufacturing industry concerning innovation capabilities has been performed to check whether the mean innovation capabilities in either of the industry is different or not. From the analysis, the following results have been generated.

\section{Independent Samples Test}

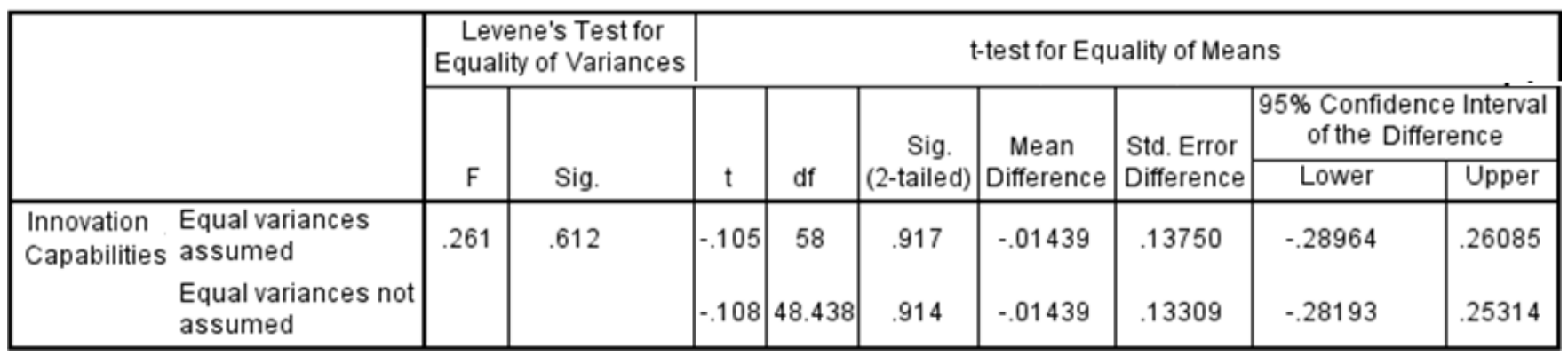

From the analysis, it has been determined that innovation capabilities for both service and manufacturing firms are indifferent and both the firms are capable of innovation concerning CRM in its operations. However, from the quantitative analysis conducted above, it has been determined that since the number of manufacturing firms for this study is more, the CRM has a significant impact on innovation capabilities within the manufacturing industry more as compared to the service industry.

\section{Discussion}

By the findings obtained from correlation and regression, it was evident that correlation exists between all dependent and independent variables whereas strong relationship exists with customer involvement, joint problem solving 
and technology-based CRM because sig-values are less than 0.05. Result leads to the fact that CRM has a strong influence on innovation capabilities through three most vital factors. However, this does not indicate that information sharing and long-term partnership are not important because the study conducted by Doney and Cannon (1997) signifies that information sharing as an important element or medium used to transfer necessary information whereas long-term partnership is referred to as a essential component for building a strong relationship.

The result can be different concerning Industry-wise, Country wise, competition wise and there are possibly many more reasons. The study of Doney and Cannon 1997 which has been conducted in America, tells that information sharing is a vital factor for the relationship of buyer and seller, while my study explains there is moderate relationship with innovation. Here the question arises, are Pakistani industries freely shares their information, like product information, demand information vendors information, financial information, process information, etc. The reason can be trust-level, loss of crucial information, and hiding profits margins. This hesitation arises due to bad governance and weak reforms and regulations. So, we can say in Pakistan organizations hesitate to share information, which could be a barrier in the successful implementation of CRM.

Furthermore, long-term partnership also has moderate relationship with innovations because; Pakistani industries are also hesitated that their power and dependencies may shift to their customer end which could make an end of their existence. So it can be said because of the third world economy and weak laws and regulations, the variables do react abnormally, as compare to other strong economies. To lift these barriers, both government and organizations need to work on; government should strengthen the economy, bring merit in every field and develop healthy and effective reforms, while organization can intensify their information technology and R\&D.

Furthermore, the findings of the study have also indicated that customer involvement, joint problem solving and technology-based CRM are factors that trigger innovation in an organization. With the advancement of technology, customer feedback and their participation in service offering is considered to be vital for the manufacturing and service industry. However, despite the fact that most firms find customers to be critical for their decision making still, the service industry requires customer data insights more as they are in direct contact with the customers and can know the needs and preferences of customers more readily. The result validates the study conducted by Pratt (2007) which has shed light on the role of CRM and how significant it is for increasing customer value.

Moreover, the researcher had also determined that apart from customer involvement and technology-based CRM, joint problem solving is also an vital factor. Ritter and Walter (2003) identified that for the growth and smooth sustainability of manufacturing and service industry, joint problem solving is an effective method that can help develop a product and offer quality services through twoway involvement of both parties. Some of the studies conducted in this domain had presented manufacturing industry as a complex unit with minimal customer interaction whereas some studies shed light on enhancing CRM in manufacturing as well as service industries so that desired targets such as increased customer loyalty, customer satisfaction, profitability, footfall, and sales can be increased. The overall aim and objective of the study were achieved successfully with the help of the above results obtained through the rapid response of employees working in manufacturing and service industry of Pakistan.

\section{CONCLUSION}

The following study aims to examining the impact of customer relationship management on innovation capabilities while comparing the services and manufacturing industries of Pakistan. The analysis showed that largely respondents were employed in the manufacturing sector. The techniques applied included correlation and regression analysis. The variables used in this study were long-term partnership, information sharing, customer involvement, joint problem solving, and technology-based CRM, which were taken into consideration as measures for CRM. For the dependent variable that is innovation capabilities, three variables used as measures for innovation capabilities. The three variables were processed innovation, product innovation, and service innovation. In this context, the correlation analysis overall revealed that there is a significant relationship between all the independent variables measuring CRM concerning innovation capabilities. Furthermore, the correlation analysis disclosed that innovation capabilities had a strong relationship with long-term partnership, information sharing, and technology-based CRM. However, innovation capabilities had a moderate bond with joint problem solving and customer involvement.

On the other hand, the regression analysis revealed that all the independent variables could firmly predict the innovation capabilities strongly having an R-square of $82.1 \%$. However, the overall regression analysis depicted that individually, customer involvement, joint problem solving and technology-based CRM significantly impact innovation capabilities yet there was no significant impact of long-term partnership and information sharing on innovation capabilities. Among the variables having considerable impact, joint problem solving and technology-based CRM had influence on innovation capabilities. Technology is the most influential indicator of CRM; companies may enhance the application of ERP and CPFR to effectively engage the customer into innovations programs, while customer involvement had a negative impact. To achieve outcome, firms must foresee internal efforts and embrace collaborative activities with their customers. As supply chain management is progressing 
with the aid of more advanced IT, the potential influence of customer involvement on innovation capability could increase. Overall from the results, it has been depicted that CRM has a strong influence on innovation capabilities of manufacturing firms in Pakistan as most of the data was collected from manufacturing industry while the study produced minimal results regarding service industry.

\section{FUTURE IMPLICATIONS}

For future research suggestions, it has been determined that the study to be conducted in a specific industry of Pakistan to narrow down the scope of study for further getting indepth results. The sample size can be increased by future researchers for more generalizability of result. The future researchers can also include or exclude variables that are insignificant in this study to determine whether results stay the same or contradict the current study.

\section{REFERENCES}

Amjad, M. (2017). Drivers Impacting Relationship Quality and Customer Loyality in Logistics Outsourcing: Pakistan Perspective. Asian Business Review, 7(3), 111-120.

Bernard, H.R. and Bernard, H.R., 2012. Social research methods: Qualitative and quantitative approaches. Sage.

Blattberg, R.C. and Deighton, J., 1996. Manage marketing by the customer equity test. Harvard business review, 74(4), p.136

Chang, S. and Lee, M.S. (2008), "The linkage between knowledge accumulation capability and organizational innovation", Journal of Knowledge Management, Vol. 12 No. 1, pp. 3-20.

Creswell, R. 2014. Research design: qualitative, quantitative, and mixed methods approaches. USA: Sage Publications

Damanpour, F. (1996), “Organizational complexity and innovation: developing and testing multiple contingency models", Management Science, Vol. 42 No. 5, pp. 693-716.

Doney, P.M. and Cannon, J.P., 1997. An examination of the nature of trust in buyer-seller relationships. The Journal of Marketing, pp.35-51

Fickel, L. (1999), “Know your customer," CIO Magazine, Vol. 12 No. 21, pp. 62-72

Fruhling, A.L. and Siau, K. (2007), “Assessing organizational innovation capability and its effect on e-commerce initiatives", The Journal of Computer Information Systems, Vol. 48 No. 1, pp. 133-45

Gopalakrishnan, S. and Damanpour, F. (1997), “A review of innovation research in economics, sociology and technology management", Omega, Vol. 25 No. 1, pp. 147-66.

Handfield, R.B. and Bechtel, C., 2002. The role of trust and relationship structure in improving supply chain responsiveness. Industrial marketing management, 31(4), pp.367-382

Heide, J.B. and John, G., 1992. Do norms matter in marketing relationships?. The Journal of Marketing, pp.32-44

Kepner C. and Tregoe B. (1965) The Rational Manager. McGraw Hill, New York

Lewis, S., 2015. Qualitative inquiry and research design: Choosing among five approaches. Health promotion practice, 16(4), pp.473-475.

Liao, S.H., Fei, W.C. and Chen, C.C. (2007), "Knowledge sharing, absorptive capacity, and innovation capability: an empirical study of Taiwan's knowledge-intensive industries", Journal of Information Science, Vol. 33 No. 3, pp. 340-59.

Lin, R.J., Chen, R.H. and Kuan-Shun Chiu, K., 2010. Customer relationship management and innovation capability: an empirical study. Industrial Management \& Data Systems, 110(1), pp.111-133

Lin, X. and Germain, R., 2004. Antecedents to Customer Involvement in Product Development:: Comparing US and Chinese Firms. European Management Journal, 22(2), pp.244-255

Mohr, J. and Spekman, R., 1994. Characteristics of partnership success: partnership attributes, communication behavior, and conflict resolution techniques. Strategic management journal, 15(2), pp.135-152

Nadeem, K., \& Siddiqui, D. (2017). The Effect of Strategic Orientation on Green Supply Chain Practices and Performance: A Case of Manufacturing Companies in Pakistan. Asian Business Review, 7(2), 59-70.

Peppers, D. and Rogers, M., 1999. The One to One Manager: RealWorld Lessons in Customer Relationship Management, Doubleday, New York, NY

Pratt, J., 2007. What is CRM. Construction Business Development, 71.

Ramani, G. and Kumar, V. (2008), "Interaction orientation and firm performance," Journal of Marketing, Vol. 72 No. 1, pp. 27-45

Ritchie, J., Lewis, J., Nicholls, C.M. and Ormston, R. eds., 2013. Qualitative research practice: A guide for social science students and researchers.

Saha, A., Hasan, K., \& Uddin, M. (2014). A Conceptual Framework for Understanding Customer Satisfaction in Banking Sector: The Mediating Influence of Service Quality and Organizational Oath. American Journal of Trade And Policy, 1(2), 85 - 93.

Saunders, M.N. and Lewis, P., 2012. Doing research in business \& management: An essential guide to planning your project. Pearson.

Schumpeter, J.A.; 1978. Redvers Opie. The Theory of Economic Development (Theorie der wirtschaftlichen Entwicklung, 1934), Oxford University Press, p.65.

Shane, S.A. and Ulrich, K.T., 2004. 50 ${ }^{\text {th }}$-anniversary article: Technological innovation, product development, and entrepreneurship in management science. Management Science, 50(2), pp.133-144

Sin, L.Y., Tse, A.C. and Yim, F.H., 2005. CRM: conceptualization and scale development. European Journal of marketing, 39(11/12), pp.1264-1290

Smith, J.A. ed., 2015. Qualitative psychology: A practical guide to research methods. Sage.

Taylor, S.J., Bogdan, R. and DeVault, M., 2015. Introduction to qualitative research methods: A guidebook and resource. John Wiley \& Sons.

Verhoef, P.C. and Donkers, B., 2001. Predicting customer potential value an application in the insurance industry. Decision support systems, 32(2), pp.189-199

Walter, A. and Ritter, T., 2003. The influence of adaptations, trust, and commitment on value-creating functions of customer relationships. Journal of Business \& Industrial Marketing, 18(4/5), pp.353-365

$--0--$ 